\title{
Correction to: Reprogramming of gene expression in Escherichia coli cultured on pyruvate versus glucose
}

\author{
Anna Chao Kaberdina ${ }^{1}$ - Olatz Ruiz-Larrabeiti ${ }^{2} \cdot$ Sue Lin-Chao $^{1} \cdot$ Vladimir R. Kaberdin $^{2,3,4}$ (D)
}

Published online: 20 August 2019

(c) The Author(s) 2019

\section{Correction to: Molecular Genetics and Genomics https://doi.org/10.1007/s00438-019-01597-1}

The article Reprogramming of gene expression in Escherichia coli cultured on pyruvate versus glucose, written by Anna Chao Kaberdina, Olatz Ruiz-Larrabeiti, Sue Lin-Chao and Vladimir R. Kaberdin, was originally published electronically on the publisher's internet portal (currently SpringerLink) on 30 July 2019 without open access.

With the author(s)' decision to opt for Open Choice the copyright of the article changed on 23 August 2019 to () The Author(s) 2019 and the article is forthwith distributed under the terms of the Creative Commons Attribution 4.0 International License (http://creativecommons.org/licen ses/by/4.0/), which permits use, duplication, adaptation, distribution and reproduction in any medium or format, as long as you give appropriate credit to the original author(s) and the source, provide a link to the Creative Commons license and indicate if changes were made. The original article has been corrected.

Open Access This article is distributed under the terms of the Creative Commons Attribution 4.0 International License (http://creativecommons.org/licenses/by/4.0/), which permits unrestricted use, distribution, and reproduction in any medium, provided you give appropriate credit to the original author(s) and the source, provide a link to the Creative Commons license, and indicate if changes were made.

Publisher's Note Springer Nature remains neutral with regard to jurisdictional claims in published maps and institutional affiliations.
The original article can be found online at https://doi.org/10.1007/ s00438-019-01597-1.

\section{Sue Lin-Chao}

mbsue@gate.sinica.edu.tw

$\triangle$ Vladimir R. Kaberdin

vladimir.kaberdin@ehu.eus

1 Institute of Molecular Biology, Academia Sinica, Taipei 11529, Taiwan

2 Department of Immunology, Microbiology and Parasitology, University of the Basque Country UPV/EHU, Leioa, Spain

3 IKERBASQUE, Basque Foundation for Science, Maria Diaz de Haro 3, 48013 Bilbao, Spain

4 Research Centre for Experimental Marine Biology and Biotechnology (PIE-UPV/EHU), 48620 Plentzia, Spain 